\title{
Salivary gland is capable of GH synthesis under GHRH stimulation
}

\author{
J A F Tresguerres, C Ariznavarreta, B Granados, J A Costoya ${ }^{1}$, \\ A Pérez-Romero, F Salamé and M Hermanussen ${ }^{2}$ \\ Department of Physiology, Medical School, Complutense University, Madrid, Spain \\ ${ }^{1}$ Department of Physiology, Medical School, University of Santiago de Compostela, Santiago de Compostela, Spain \\ ${ }^{2}$ Aschauhof, Altenhof, Kiel, Germany \\ (Requests for offprints should be addressed to J A F Tresguerres)
}

\begin{abstract}
Twelve female rats weighing $\sim 150 \mathrm{~g}$ received in the submaxillary gland a pellet capable of releasing $3 \cdot 5 \mu \mathrm{g}$ GHRH/h for 60 days. Another eight sex- and weightmatched animals received placebo pellets in the same place. After two months the animals were killed, heart blood was collected and pituitary and submaxillary glands were carefully dissected. Pituitary GH content in both placebo- and GHRH-treated animals showed similar values, but plasma GH and IGF-I levels were significantly lower in the animals carrying GHRH pellets $(P<0 \cdot 03)$;
\end{abstract}

these animals also had a significantly higher GH content in the submaxillary gland $(19 \cdot 2 \pm 8 \mathrm{ng} / \mathrm{mg}$ protein $) \mathrm{com}-$ pared with the placebo-treated group $(1 \cdot 1 \pm 0 \cdot 3 \mathrm{ng} / \mathrm{mg}$ protein). GH mRNA was present only in the submaxillary gland of GHRH-treated rats as determined by PCRSouthern blot and by in situ hybridization methods. It is concluded that high local GHRH levels are capable of inducing transdifferentiation in submaxillary gland cells to synthesize GH.

Journal of Endocrinology (1999) 160, 217-222

\section{Introduction}

Previous data from our studies have shown that parotid gland tissue is capable of partially assuming pituitary functions when influenced by hypothalamic hormones both in vivo (Álvarez-Vega et al. 1991, Granados et al. 1993) and in vitro (Fernández et al. 1994). Thus, parotid cells when submitted to hypothalamic extracts were able to synthesize and secrete at least luteinizing hormone (LH), follicle-stimulating hormone, thyrotrophin and growth hormone $(\mathrm{GH})$. In these studies, LH secretion by parotid tissue was found to be related to the dose of hypothalamic extract used and to the presence of $\mathrm{LH}$ releasing hormone $(\mathrm{LHRH})$; a dramatic reduction in $\mathrm{LH}$ values was detected when the hypothalamic extract used had previously been treated with a specific antibody against LHRH.

This study has been designed in order to see if $\mathrm{GH}$ releasing hormone (GHRH) by itself is capable of inducing morphofunctional changes in submaxillary glands when administered in vivo at high continuous concentrations.

\section{Materials and Methods}

Twenty female Wistar rats weighing $157 \pm 3 \mathrm{~g}$ (range 142-173 g) were used. Animals were kept in Macrolon cages under controlled conditions of temperature $\left(21 \pm 2{ }^{\circ} \mathrm{C}\right)$ and light $(12 \mathrm{~h} \mathrm{light} / 12 \mathrm{~h}$ darkness $)$, with tap water and rat chow (Panlab, Barcelona, Spain) available ad libitum. The studies were conducted in accordance with the principles and procedures outlined in the NIH Guide for the Care and Use of Laboratory Animals. All animals were implanted with a slow release pellet (Innovative Research of America, Sarasota, FL, USA) in the right submaxillary gland under light ether anaesthesia. Group A (12 rats) received a pellet loaded with $5 \mathrm{mg}$ GHRH 1-29 $\mathrm{NH}_{2}$ (GRF; Bachem, Bubendorf, Switzerland) allowing a continuous peptide release for 60 days $(3 \cdot 5 \mu \mathrm{g} / \mathrm{h})$. Group B (8 rats) received placebo pellets. Animals were weighed each week.

After 60 days, the submaxillary glands were dissected out under ether anaesthesia. Glands were halved: one half was immediately frozen in liquid nitrogen and the other half was kept at $-20{ }^{\circ} \mathrm{C}$. Blood was drawn from the heart, the rats were killed by decapitation and their pituitary glands carefully removed and also kept frozen at $-80{ }^{\circ} \mathrm{C}$ until analysed.

\section{Protein estimation}

Protein content was determined in homogenates of pituitary and submaxillary glands by the Brilliant Blue method (Bradford 1976). The homogenates were obtained by sonication (Branson sonifier 450), the tissues were processed in saline solution and then centrifuged for 
15 min at 3000 r.p.m. at $4{ }^{\circ} \mathrm{C}$. The colouring reagent was added to the supernatant and the sample read in a Spectrophotometer (U-1100 Hitachi). A reference curve was prepared with bovine serum albumin (Sigma, St Louis, MO, USA).

\section{Hormone determination}

For the $\mathrm{GH}$ determinations, the reagents provided by the NIADDK (Baltimore, MD, USA) were used as previously described (Lima et al. 1993). The iodination of rat GH I-6 was performed using lactoperoxidase (Thorell \& Johansson 1971). The standard used was rat GH r-p2 and the sensitivity of the curve was $25 \mathrm{pg} / \mathrm{ml}$. The intra- and interassay coefficients of variation were $5 \cdot 7 \%$ and $9 \cdot 4 \%$ respectively. Insulin-like growth factor I (IGF-I) was measured using the antibody (UB2-495) provided by the NIADDK. The IGF-I used for iodination (by the Chloramine T method) and standard curve dilution was A 52-EDP-186 (Lilly Company, Indianapolis, IN, USA). The assay was performed following the method of Daughaday et al. $(1980,1982)$ as previously described by our group (Hermanussen et al. 1996). The sensitivity of the curve was $10 \mathrm{pg} / \mathrm{ml}$, and the intra- and interassay coefficients of variation were $7 \cdot 8 \%$ and $12.9 \%$ respectively. Plasma GH was measured directly and plasma IGF-I was estimated after acid-ethanol extraction. For the estimation of both GH and IGF-I content, halved submaxillary and pituitary glands were homogenized in saline and centrifuged. Measurements were carried out in the supernatant. GH was determined directly and IGF-I after acid-ethanol extraction.

\section{Extraction of GH $m R N A$ and $c D N A$ synthesis}

A portion of the rat submaxillary glands, kept at $-80{ }^{\circ} \mathrm{C}$ and from rats treated with GHRH or placebo pellets were homogenized and mRNA was extracted using poly-dT coupled particles (Quick-Prep mRNA micro purification kit; Pharmacia, Biotech, Uppsala, Sweden). Pituitary glands from normal animals were used as a positive control of the amplified product.

The extracted mRNA was used for the synthesis of cDNA using $200 \mathrm{IU}$ Moloney murine leukaemia virus reverse transcriptase, $20 \mathrm{mM}$ Tris $-\mathrm{HCl} \mathrm{pH} 8 \cdot 3,50 \mathrm{mM}$ $\mathrm{KCl}, 5 \mathrm{mM} \mathrm{MgCl}_{2}, 1 \mathrm{mM}$ dNTP, $30 \mathrm{U}$ RNAase inhibitor, $10 \mathrm{mM}$ dithiothreitol, $1 \times 10^{-6} \mathrm{M}$ oligonucleotide $3^{\prime}$ and was then used in the amplification reaction. This entire extracted sample was submitted to a cycle of $37^{\circ} \mathrm{C}$ for $50 \mathrm{~min}, 42{ }^{\circ} \mathrm{C}$ for $15 \mathrm{~min}$ and $95{ }^{\circ} \mathrm{C}$ for $5 \mathrm{~min}$.

\section{PCR and Southern blot}

Two specific primers, upstream $5^{\prime}$ TTGCTTCGCTT CTCGCTGCT $\quad 3^{\prime} \quad(1820-1840 \mathrm{nt})$, downstream $5^{\prime}$ AAGCGGCGACACTTCATGAC $3^{\prime} \quad(2342-2361 \mathrm{nt})$
(25 pmol each) for the GH gene (Barta et al. 1981) were used for the amplification of GH cDNA by PCR, in the presence of $1 \mathrm{U}$ Taq polymerase, $18.6 \mathrm{mM}$ Tris- $\mathrm{HCl}$, $45.9 \mathrm{mM} \mathrm{KCl}, 3 \mathrm{mM} \mathrm{MgCl} 2$, and $2 \mathrm{mM}$ dNTP. Thirty 1 -min cycles at $94{ }^{\circ} \mathrm{C}, 55^{\circ} \mathrm{C}, 72{ }^{\circ} \mathrm{C}$ and a final $10-$ min cycle at $72{ }^{\circ} \mathrm{C}$ were run.

Results were visualized in 1\% agarose gel electrophoresis with ethidium bromide staining under UV light.

The agarose gel was blotted onto a Hybond- $\mathrm{N}^{+}$nylon membrane (Amersham Life Science, Amersham, Bucks, UK) under $0.5 \mathrm{M} \mathrm{NaOH}$ overnight. The prehybridization was performed at $57^{\circ} \mathrm{C}$ for $3 \mathrm{~h}$ in $50 \times$ Denhardt's solution (1\% Ficoll, $1 \%$ polyvinylpyrrolidone and 1\% BSA), $20 \times$ SSPE, $10 \%$ SDS and $10 \mathrm{mg} / \mathrm{ml}$ denatured salmon sperm DNA. Hybridization was carried out in the same buffer as that in the prehybridization step using a ${ }^{32} \mathrm{P}-$ labelled specific probe for $20 \mathrm{~h}$ at $57^{\circ} \mathrm{C}$. After the hybridization, the membrane was washed five times in $6 \times \mathrm{SSC}$ for $20 \mathrm{~min}$ at $57^{\circ} \mathrm{C}$. The blots were exposed overnight to $\mathrm{X}$-ray film at $-80^{\circ} \mathrm{C}$ with an intensifying screen and developed by standard procedures.

\section{In situ hybridization}

Halved pituitary glands of control rats and the remaining portion of the submaxillary glands of the rats treated with the GHRH or placebo pellets, were kept at $-80{ }^{\circ} \mathrm{C}$ and were used for in situ hybridization. The tissues were cut in a cryostat (Slee, Mainz, Germany) in sections of 7-10 $\mu \mathrm{m}$.

A specific synthetic probe for GH (5' GACTGGATG AGCAGCAGCGAGAAGCG 3') was non-radioactively labelled by the incorporation of digoxigenin. After hybridization the oligonucleotide-labelled probe was found to target nucleic acids in the pituitary or in the submaxillary gland as determined by enzymelinked immunoassay using an antibody conjugate (antidigoxigenin alkaline phosphate conjugate, anti-DIGAP). A subsequent enzyme-catalysed colour reaction with 5-bromo-4-chloro-3-indolyl-phosphate (BCIP) (Boehringer Mannheim, Barcelona, Spain) and nitroblue tetrazolium salt (NTB) (Boehringer Mannheim) produced an insoluble blue precipitate, which indicates hybrid molecules.

To avoid the possibility of non-specific (proper) signals, some sections were treated with ribonucleases (Ribonuclease A, Ribonuclease $\mathrm{T}_{1}$, Sigma) before hybridization. Another control was performed avoiding the use of anti-DIG-AP.

\section{Statistical evaluation}

Data are presented as means \pm S.E.M. Comparisons between the groups were made by Student's $t$-test analysis for unpaired means. 


\section{Results}

Body weight at the beginning of the experiment was $157 \pm 3 \cdot 3 \mathrm{~g}$ in group $\mathrm{B}$ and $157 \cdot 5 \pm 2 \cdot 9 \mathrm{~g}$ in group A rats. From the 4th week onwards, a significant attenuation of weight increase was observed in rats in group A. At the end of the experiment the placebo group weighed $274 \pm 8.4 \mathrm{~g}$ and the GHRH-treated animals weighed $257 \pm 6 \mathrm{~g}(P<0 \cdot 01)$.

GH content of pituitary glands of both GHRH- and placebo-treated rats showed similar values $(185 \pm 39 \mu \mathrm{g} /$ mg vs $197 \pm 25 \mu \mathrm{g} / \mathrm{mg}$ ) but plasma levels were significantly lower in the animals implanted with GHRH pellets $(5 \cdot 5 \pm 0.8$ vs $24 \pm 9 \mathrm{ng} / \mathrm{ml}, P<0 \cdot 03)$. This diminution was also observed in the IGF-I plasma levels of GHRHtreated rats $(1 \cdot 1 \pm 0 \cdot 07$ vs $1 \cdot 6 \pm 0 \cdot 1 \mu \mathrm{g} / \mathrm{ml}, \quad P<0 \cdot 01)$ (Fig. 1).

In the 8 animals in group $\mathrm{B}$, the $\mathrm{GH}$ content of the submaxillary glands was $1 \cdot 1 \pm 0 \cdot 3 \mathrm{ng} / \mathrm{mg}$ protein whereas in 7 of the 12 rats treated with GHRH pellets, GH content was $19 \cdot 2 \pm 8 \mathrm{ng} / \mathrm{mg}(P<0 \cdot 01)$ (Fig. 2). There was no significant difference in the IGF-I content of placebo- or GHRH-treated rats (group B, $3 \cdot 6 \pm 0.6 \mathrm{ng} / \mathrm{mg}$ protein; group A, $3 \cdot 1 \pm 0 \cdot 4 \mathrm{ng} / \mathrm{mg}$ protein).

mRNA for GH was absent in the glands from placebotreated rats but was present in tissue from GHRH-treated rats. In the 7 animals showing significant GH content, a good correlation was found with the semiquantitative mRNA determination (Fig. 3). GH mRNA was confirmed by Southern blot in the glands of GHRH-treated rats.

In situ hybridization for $\mathrm{GH}$ in all the pituitaries used was positive, and the signal disappeared when the tissues were pretreated with ribonucleases, or were not treated with anti-DIG-AP. The rats implanted with the GHRH pellet and showing high GH content in the submaxillary gland by RIA or PCR-Southern blot presented specific $\mathrm{GH}$ hybridization, which was always absent in controls with a placebo pellet (Fig. 4).

\section{Discussion}

Morphofunctional changes are also possible in adult tissues, as has been shown by several authors (Potter et al. 1986, Bellows et al. 1990, Kasper et al. 1990) and also our group (Fernández et al. 1994).

Parotid gland tissue submitted to the influence of crude hypothalamic extracts was able to assume some pituitary functions including GH synthesis (Granados et al. 1995). This was also true when the parotid gland cultures were treated with synthetic hypothalamic hormones, although in this case the effect was less marked (Fernández et al. 1994), probably indicating the existence of unknown enhancers in the crude hypothalamic extract.

Since hypothalamic hormones have also been shown to play a role in pituitary differentiation (Khorram et al. 1983,
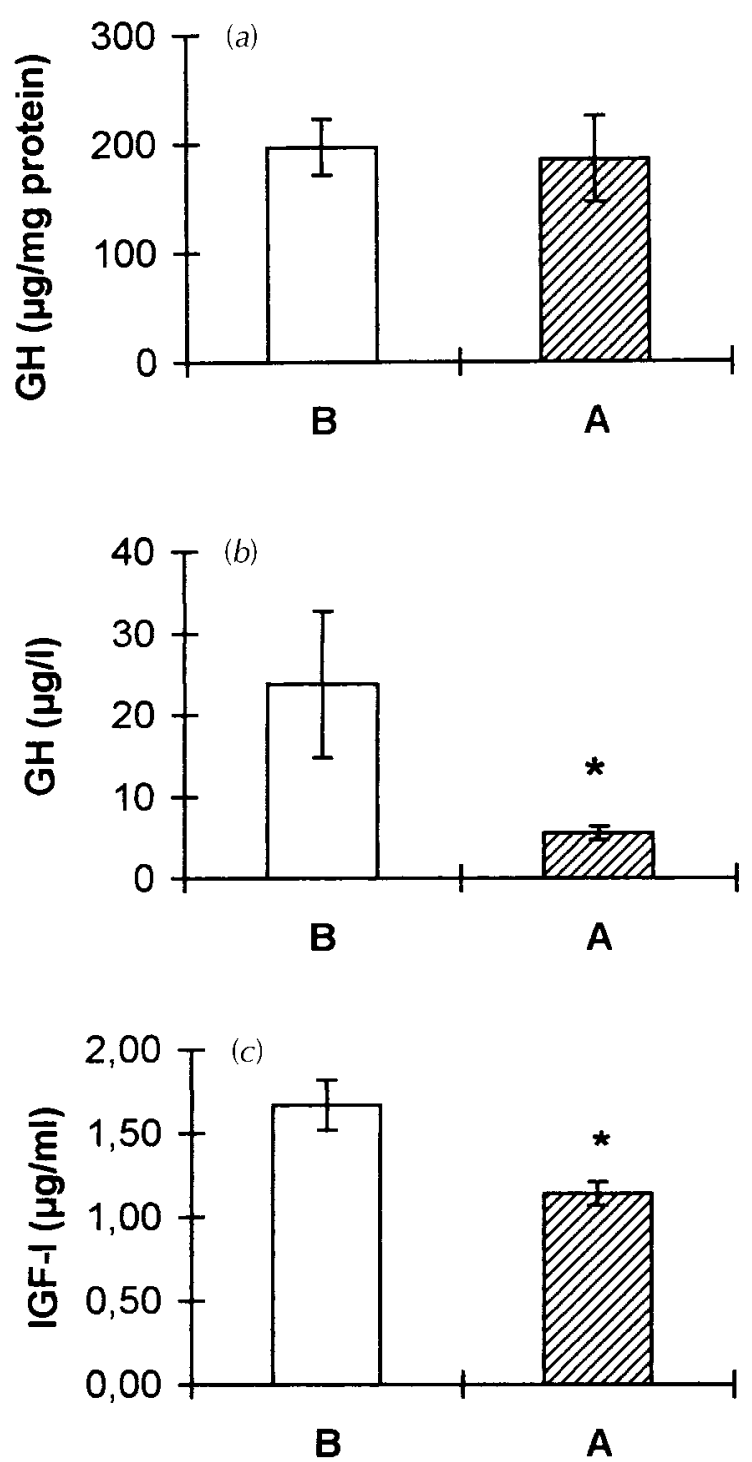

Figure 1 (a) Pituitary $\mathrm{GH}$ content, (b) plasma GH levels and (c) plasma IGF-I levels in GHRH-treated (group $A, n=12$ ) and placebo-treated (group $\mathrm{B}, n=8$ ) rats. ${ }^{*} P<0.03$ in $(b),{ }^{*} P<0.01$ in (c).

Heritier \& Dubois 1994) the present study was performed to confirm the possible transdifferentiating effect of GHRH on submaxillary glands in vivo. Using continuous release pellets charged with GHRH, nearly $60 \%$ of the treated animals showed, two months later, GH content and GH mRNA in the submaxillary gland tissue as determined by PCR-Southern blot and by in situ hybridization. Animals treated with placebo were negative for GH mRNA in the two systems used, although low GH-like contents were detected by RIA. Since salivary glands are known to produce at least some peptide hormones (Hauser-Kronberger et al. 1992) and especially 


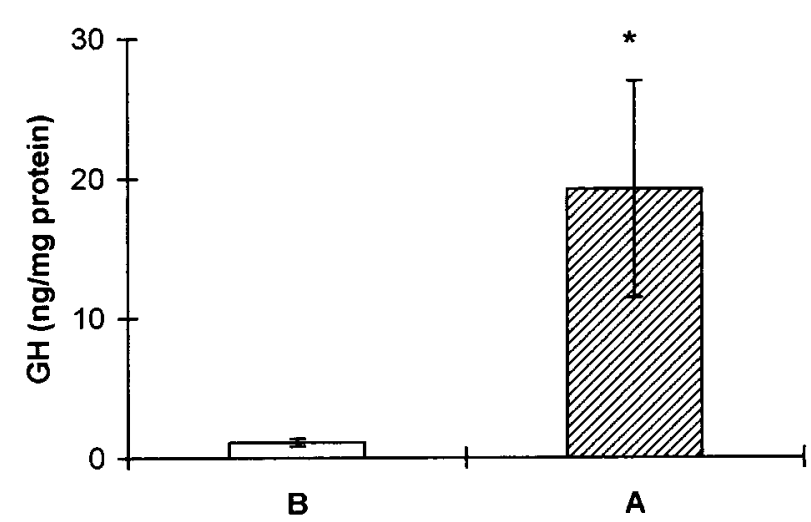

Figure $2 \mathrm{GH}$ content in the submaxillary gland of $\mathrm{GHRH}$-treated (group A) and placebo-treated (group B) rats. ${ }^{*} P<0 \cdot 01$.

growth factors (Thesleff et al. 1988, Ryan et al. 1992, Amano et al. 1993), the possibility of a persisting genomic situation allowing $\mathrm{GH}$ synthesis cannot be ruled out, although the absence of GH mRNA by PCR-Southern blot and in situ hybridization in the placebo-treated animals does not support this theory. However, the high local content of growth factors, and especially epidermal

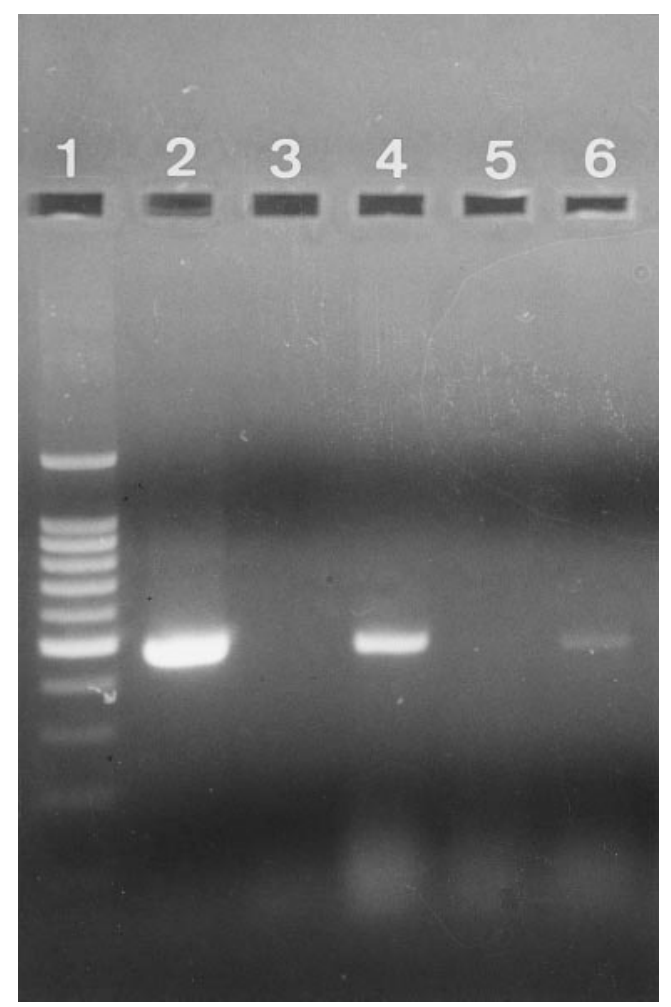

Figure $3 \mathrm{GH}$ cDNA obtained after PCR in submaxillary glands of GHRH-treated rats (lanes 4 and 6), and the absence of GH cDNA in placebo-treated rats (lanes 3 and 5). Lane 2, positive control in pituitary; lane 1, molecular weight markers. growth factor from the submaxillary gland could at least play an important role in the GHRH-induced $\mathrm{GH}$ synthesis (Ikeda et al. 1984).

Another possibility arises in which high GHRH levels could induce GH synthesis in tissues other than the pituitary, as was originally suggested by Leveston et al. (1981). This was also observed in some cases of GHRHproducing tumours, but in these cases the GH was thought to be an artefact (Caplan et al. 1978). Pancreatic tumours which cause acromegaly, in which GHRH was isolated for the first time (Guillemin et al. 1982, Rivier et al. 1982), could also have produced GH.

GHRH is not only capable of stimulating GH synthesis and release at the pituitary level (Devesa et al. 1992) but also enhances somatotrophic proliferation (Sano et al. 1988), resulting in pituitary hyperplasia through c-fos expression (Billestrup et al. 1987). However, Melmed et al. (1985) considered that it was highly unlikely that GHRH stimuli alone were sufficient to initiate the multistep process of pituitary tumorigenesis, since the pituitaries of patients with ectopic GHRH production have hyperplasia but not adenoma (Sano et al. 1988). Our data indicate that very high local GHRH levels in the submandibular salivary gland, as obtained with the GHRH pellets, are capable of stimulating GH synthesis after 2 months, in accordance with an evident action of GHRH.

This could perhaps explain an apparent discrepancy. Various cases of acromegaly due to ectopic GHRH secretion have been published (Guillemin et al. 1982, Rivier et al. 1982, Sano et al. 1988). In all of them the source of the high plasma GH levels responsible for the disease was assumed to be the hyperplastic pituitary. When GHRH, at four different dosages for 1 month, was given continuously to human volunteers by the s.c. route using portable infusion pumps, no modification or an increase in the GH secretion pattern appeared. If this infusion was maintained for 6 months or more, as was the case in a group of 5 children with idiopathic $\mathrm{GH}$ deficiency, there was an initial important increase in growth velocity. However, a very dramatic reduction in this parameter was observed after 4 months, with complete cessation after 6 months (Tresguerres et al. 1993). These data indicate a desensitizing effect of the continuously administered GHRH as is already known for LHRH (Knobil 1980) albeit with a much longer latency period. The down-regulation was confirmed in dogs using slow release GHRH microcapsules. One month following the injection a marked reduction in plasma GH levels was observed as compared with placebo-treated animals, together with an almost complete depletion of the pituitary GH content (J Devesa, L Limaand and V Arce, unpublished observation). Rats submitted to continuous GHRH administration showed, after three weeks, a marked pituitary hyperplasia but the GH content was not increased (Ariznavarreta et al. 1994). All these data support the existence of a down-regulatory mechanism in pituitary 

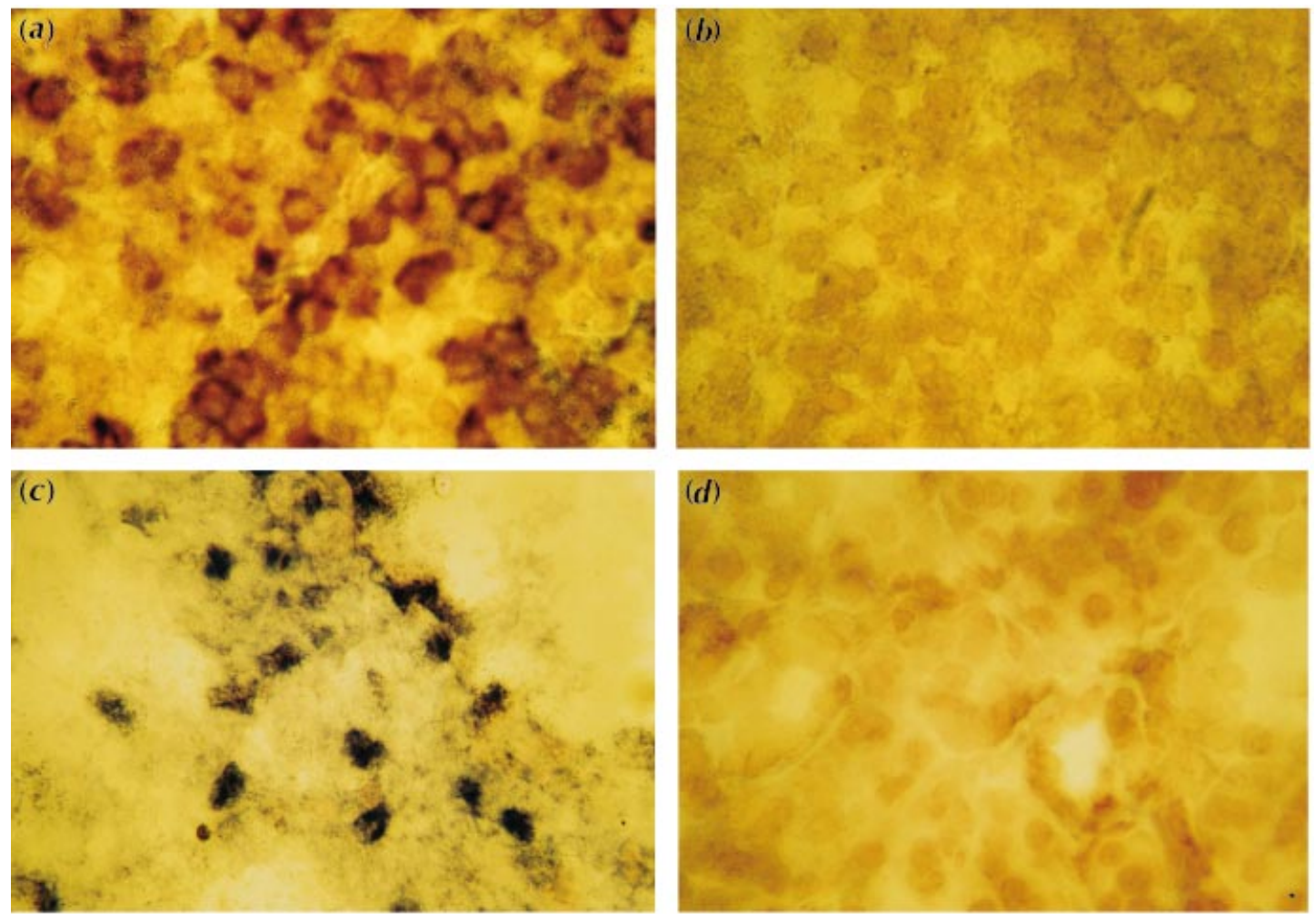

Figure 4 (a) In situ hybridization of a normal pituitary. (b) Absence of signal in a pituitary when treated with ribonucleases. (c) Positive staining of a submaxillary gland from a GHRH-treated rat. (d) Absence of response in a submaxillary gland from a placebo-treated rat. Scale bar represents $115 \mu \mathrm{m}$.

GH secretion when submitted to continuous GHRH stimulation. If this is the case, one possible explanation for the acromegalies in ectopic GHRH-secreting tumours could be that at least part of the GH production originates in the tumour itself, as our data with the pellets suggest.

The high amounts of GHRH released at the submaxillary level also seem to exert a negative feedback on GH secretion, since GH and IGF-I plasma levels are significantly reduced and body weight is lower. This effect of $\mathrm{GHRH}$, as the inductor of $\mathrm{GH}$ formation, could be produced through the synthesis of Pit-1 (Fox 1990, Delhase et al. 1993) in the salivary gland and other tissues, but this theory needs to be investigated further.

\section{Acknowledgements}

We are indebted to the NIADDK for the supply of antibodies and standard for GH RIA, to Lilly Co. for the gift of IGF-1 standard and to Lucila Kraus for her technical assistance.

This work has been possible through grants FISS 92/0475 and FISS 96/1084.

\section{References}

Álvarez-Vega P, Gil-Loyzaga P, Alvarez-Buylla R \& Tresguerres JAF 1991 Partial pituitary function of parotid gland tissue autotransplanted to the sella turcica after hypophysectomy. Endocrine Society Meeting, Washington, USA, 1991. Abstract 416.

Amano O, Yoshitake Y, Nishikawa K \& Iseki S 1993 Basic fibroblast growth factor in rat salivary glands. Cell Tissue Research $\mathbf{2 7 3}$ 467-474.

Ariznavarreta C, Pérez-Romero A, Rol de Lama MA, Granados B \& Tresguerres JAF 1994 Regulación de GH por GHRH a largo plazo en la rata. Endocrinología 41 (Suppl 3) 16.

Barta A, Richards RI, Baxter JD \& Shine J 1981 Primary structure and evolution of rat growth hormone gene. Proceedings of the National Academy of Sciences of the USA 78 4867-4871.

Bellows CG, Ishida H, Aubin JE \& Heersche JN 1990 PTH reversibly suppresses the differentiation of osteoprogenitor cells into functional osteoblast. Endocrinology 127 3111-3116.

Billestrup N, Swanson LW, Vale W \& Verma IM 1987 GH releasing factor induces $\mathrm{C}$-fos expression in cultured primary pituitary cells. Molecular Endocrinology 1 300-305.

Bradford MM 1976 A rapid and sensitive method for the quantitation of microgram quantities of protein utilizing the principle of protein-dye binding. Annals of Biochemistry 72 248-254.

Caplan RH, Koob L \& Abellera R 1978 Cure of acromegaly by operative removal of an islet cell tumor of the pancreas. American Journal of Medicine 64 874-882. 
Daughaday WH, Mariz IK \& Blethen SL 1980 Inhibition of access of bound somatomedin to membrane receptor and immunobinding sites: a comparison of radioreceptor and radioimmunoassay of somatomedin in native and acid-ethanol extracted serum. Journal of Clinical Endocrinology and Metabolism 51 781-788.

Daughaday WH, Parker KA, Borowsky S, Trivedi B \& Kapadia M 1982 Measurement of somatomedin-related peptides in fetal, neonatal, and maternal rat serum by insulin-like growth factor (IGF)-I radioimmunoassay, IGF-II radioreceptor assay (RRA), and multiplication-stimulating activity RRA after acid-ethanol extraction. Endocrinology 110 575-581.

Delhase M, Vergani P, Maher A, Velkeniers B, Tengels E, Tronillas J \& Hooghe-Peters EL 1993. Pit-1/GHF-1 expression in pituitary adenomas. Journal of Molecular Endocrinology 11 129-139.

Devesa J, Lima L \& Tresguerres JAF 1992 Neuroendocrine control of GH secretion in humans. Trends in Endocrinology and Metabolism 3 175-183.

Fernández P, Granados B, Ariznavarreta C, Rodríguez-Ramos A, Gil-Loyzaga P \& Tresguerres JAF 1994 Rat parotid gland tissue is able to assume pituitary functions under hypothalamic extracts in culture. Neuroendocrinology 60 (Suppl) 36.

Fox SR 1990 The homeodomain protein Pit-1/GHF-1 is capable of binding to and activating cell-specific elements of both the GH and prolactin gene promoter. Molecular Endocrinology 4 1069-1080.

Granados B, Ariznavarreta C \& Tresguerres JAF 1993 Adrenal and parotid tissue autotransplantation to the sella turcica are able to partially recover gonadotrophic function in hypophysectomized rats. Journal of Endocrinology Investigation 16 (Suppl 8) 116.

Granados B, Fernández P, Ariznavarreta C, Gil-Loyzaga P \& Tresguerres JAF $1995 \mathrm{LH}$ and TSH values in parotid glands submitted to hypothalamic influences: in vivo and in vitro studies. Endocrine Society Meeting. Washington, USA, 1995. Abstract P2-57.

Guillemin R, Brazeau P, Bohlen P, Esch F, Ling N \& Wehrenberg WB 1982 Growth hormone-releasing factor from a human pancreatic tumor that caused acromegaly. Science 216 585-587.

Hauser-Kronberger C, Albergger K, Saria A \& Hacker GW 1992 Neuropeptides in human salivary (submandibular and parotid) glands. Acta Otolaryngological 112 343-348.

Heritier AG \& Dubois PM 1994 Re-evaluation of GnRH action on pituitary cell differentiation with special regard to its effect on $\mathrm{LH}$ and TSH cell types. Journal of Neuroendocrinology 6 33-37.

Hermanussen M, Rol de Lama MA, Pérez-Romero A, Ruiz CA, Burmeister J \& Tresguerres JAF 1996 Differential catch-up in body weight and bone growth after short-term starvation in rats. Growth Regulation 6 230-237.

Ikeda H, Mitsuhashi T, Kubota K, Kuzuya N \& Uchimura H 1984 Epidermal growth factor stimulates growth hormone secretion from perifused rat adenohypophyseal fragments. Endocrinology 115 $556-558$.
Kasper C, Fitzsimmons R, Strong D, Mohan S, Jennings J, Wergedal J \& Baylink D 1990 Studies of the mechanism by which androgens enhance mitogenesis and differentiation in bone cells. Journal of Clinical Endocrinology and Metabolism 71 1322-1329.

Khorram O, De Patalis LR \& McCann SM 1983 Development of hypothalamic control of growth hormone secretion in the rat. Proceedings of the National Academy of Sciences of the USA $\mathbf{8 5}$ 9297-9301.

Knobil E 1980 The neuroendocrine control of the menstrual cycle. Recent Progress in Hormone Research 36 53-88.

Leveston SA, McKeel DW, Buckley PJ, Deschryver K, Greider MH, Jaffe BM \& Daughaday WH 1981 Acromegaly and Cushing syndrome associated with a foregut carcinoid tumor. Journal of Clinical Endocrinology and Metabolism 53 682-689.

Lima L, Arce V, Tresguerres JAF \& Devesa J 1993 Clonidine potentiates the $\mathrm{GH}$ response to $\mathrm{GHRH}$ in norepinephrine synthesis inhibited rats: evidence for an alpha 2 adrenergic control of hypothalamic release of somatostatin. Neuroendocrinology 57 1155-1166.

Melmed S, Ezrin C, Kovacs K, Goodman R \& Frohman L 1985 Acromegaly due to secretion of growth hormone by an ectopic pancreatic islet-cell tumor. New England Journal of Medicine 312 9-12.

Potter DD, Landis SC, Matsumoto SG \& Furshpan EJ 1986 Synaptic functions in rat sympathetic neurons in microcultures. II. Adrenergic/cholinergic dual status and plasticity. Journal of Neuroscience 6 1080-1098.

Rivier J, Spiess J, Thorner MD \& Vale W 1982 Characterization of a growth hormone-releasing factor from a human pancreatic islet tumor. Nature 300 276-278.

Ryan J, Mantle T, McQuaid S \& Costigan DC 1992 Salivary insulin-like growth factor-I originates from local synthesis. Journal of Endocrinology 135 85-90.

Sano T, Asa SL \& Kovacs K 1988 GHRH producing tumours: clinical, biochemical and morphological manifestations. Endocrine Reviews 9 357-373.

Thesleff I, Vinikka L, Saxen L, Lehtonen E \& Perheentupa J 1988 The parotid gland is the main source of human salivary epidermal growth factor. Life Sciences 43 13-18.

Thorell JI \& Johansson BG 1971 Enzymatic iodination of polypetides with ${ }^{125}$ I to high specific activity. Biochimica et Biophysica Acta 251 363-369.

Tresguerres JAF, Moreno B, Lorenzo L, Garrido M \& Devesa J 1993 GRF 1-29 $\mathrm{NH}_{2}$ : new diagnostic and therapeutical perspectives. In Two Decades of Experience in Growth, pp 239-252. Eds M Pombo \& RG Rosenfeld. New York: Raven Press.

Received 29 June 1998

Accepted 25 August 1998 